\title{
Physicochemical, phytochemical and antibacterial studies of few medicinal plants of Visakhapatnam region against bacterial clinical isolates
}

Phani Kumari Uddandapu'*, K. Chandrasekhara Naidu², Y. Venkateswar Rao', ${ }^{1}$ Department of Botany, A.U. College of Science and Technology, Andhra University, Visakhapatnam-3, A.P. India.

${ }^{2}$ Vemu Institute of technology, P. Kothakota, Chittoor Dist. A.P. India.

Received: February 27, 2016; Revised: March 11, 2016; Accepted: March 17, 2016.

\begin{abstract}
The present study was conducted to evaluate the physicochemical and preliminary phytochemical studies, antimicrobial studies on sixteen medicinal plants collected in and around regions of Visakhapatnam district using methanol as a solvent. Phytochemical screening revealed that methanolic extracts, contained, steroids, alkaloids, phenol, flavonoids, polyphenols and glycosides. The physicochemical parameters like ash and extractive values were determined. The highest percentage of total ash, was found in Catharanathus roseus. The extractive values can be used as a reliable aid for detecting quality of drug adulteration. Antimicrobial efficiency of studies plants was tested against four bacterial clinical pathogens including Staphylococcus aureus, Escherichia coli, Klebsiella pneumoniae and Proteus vulgaris. The diameter of zone of inhibition (ZOI) was measured and it was found that $C$. roseus showed maximum zone of inhibition against gram+ve $S$. aureus and minimum zone of inhibition against gram-ve E. coli. Also the zone of inhibition was increased on increasing concentration. Results observed in the present study help to distinguish the plant extracts from its adulterants and quality and it may be indicative of the methanol extracts of studied plants could be a possible source to obtain new and effective herbal medicines to treat infections, which justify the ethnic uses of $C$. roseus against various infectious diseases apart from its anticancer properties.
\end{abstract}

Key words: Phytochemical; antimicrobial; phenols

\section{Introduction}

Throughout the ages, humans have relied on nature for their basic needs for the production of foodstuffs, shelters, clothing, means of transportation, fertilizers, flavors and fragrances, and, not least, medicines. Nature has been a source of medicinal agents for thousands of years and an impressive number of modern drugs have been derived from natural resources, many of these isolations were based on the uses of the agents in traditional medicine (Cragg GM, Newman DJ, 2001). The widespread use of herbal remedies and healthcare preparations, such as those described in ancient texts like the Vedas and the Bible, has been traced to the occurrence of natural products with medicinal properties. In fact, plants produce a diverse range of bioactive molecules, making them a rich source of different types of medicines. Higher plants, as sources of medicinal compounds, have continued to play a dominant role in the maintenance of human health since ancient times (Farombi EO. 2003). Since time immemorial, the traditional medicinal practices have been known for the treatment of various ailments in India. Researchers are increasingly turning their attention to the medicinal plants and it is estimated that, plant materials are present in, or have provided the models for 25-50\% of drugs [Khan R, et al., 2009; Robbers J, et al., 1996.]

Antibiotic resistance is a form of drug resistant whereby some sub-populations of a microorganism, usually a bacterial species, are able

\section{Corresponding Author}

Mrs. Phani Kumari Uddandapu,

Department of Botany,

College of Science and Technology,

Andhra University,

Visakhapatnam-530003, India. to survive after exposure to one or more antibiotics. In other word, the term "antibiotic resistance" is refers to the ability of a microorganism to withstand the effect of an antibiotic. The problem of resistance has been exacerbated by the use of antibiotics as prophylactics, intended to prevent infection before it occurs. Indiscriminate and inappropriate use of antibiotics for the treatment of the common cold and other common viral infections, against which they have no effect, removes antibiotic-sensitive bacteria and allows the development of antibioticresistant bacteria [D'Costa VM, et al., 2011].

In considering the antibiotic resistance as a major problem in the treatment of bacterial infections, there is need to find alternative way of treating infectious diseases using plants which are abundant in our environment and their extracts may overcome the antibiotic resistance so as to serve as a source of novel drugs for the treatment of these diseases. Hence, more studies pertaining to the use of plants as therapeutic agents should be emphasized, especially those related to the control of antibiotic resistant microbes. The objective of this research was to evaluate the potential of plant extracts and phytochemicals on infectious bacteria, which were isolated from clinical samples. 


\section{Materials and Methods \\ Plant Materials}

Sixteen different medicinal plants free from diseases were collected from the regions of Visakhapatnam, Andhra Pradesh, South India. The plant parts were cleaned of residual soil and airdried at room temperature.

Table 1: List of plant names

\begin{tabular}{llll}
\hline \multicolumn{1}{c}{ Plant Name } & \multicolumn{1}{c}{ Common Name } & \multicolumn{1}{c}{ Family } & Part Studies \\
\hline Senna alexandrina & Senna & Fabaceae & Leaf \\
Cinnamomum zeylanicum & Cinnamon, Dalchina & Lauraceae & Bark \\
Vitex negundo & Vavili, Nirgundi & Lamiaceae & Leaf \\
Curcuma longa & Turmeric & Zingiberaceae & Rhizome \\
Mentha arvensis & Pudina & Lamiaceae & Leaf \\
Catharanathus roseus & Periwinkle, Billaganneru & Apocynaceae & Aerial Parts \\
Ocimum sanctum & Tulasi & Lamiaceae & Aerial Parts \\
Withania somnifera & Ashwagandha & Solanaceae & Root \\
Gymnema sylvestre & Podapatri & Apocynaceae & Whole Plant \\
Symplocos racemosa & Lodhra & Symplocaceae & Bark \\
Rosmarinus officinalis & Rosemary & Lamiaceae & Aerial Parts \\
Camellia sinensis & Tea plant & Theaceae & Leaves \\
Mucuna gigantea & Enugu dulagondi, Elephant cow itch & Fabaceae & Leaves \\
Caralluma adscendens & Kundatikommulu & Asclepiadaceae & Aerial Parts \\
Baubinia purpurea & Devakanchanam, Camels foot tree & Leguminosae & Bark \\
Punica granatum & Pomegranate & Lythraceae & Peel \\
\hline
\end{tabular}

\section{Preparation of plant extracts}

The collected plant materials were dried with active ventilation at ambient temperature $\left(25 \pm 1^{\circ} \mathrm{C}\right)$ and chopped into small pieces, shade dried and coarsely powdered in Willy mill. The coarsely powdered material weighed and extracted with Methanol using a soxhlet extractor for five to six hours at temperature not exceeding the boiling point of the solvent. For each 100 grams of dry material 2 litres of solvent was used. The extracted solvents were concentrated under reduced pressure (in vacuo at $40^{\circ} \mathrm{c}$ ) using a rotary evaporator. The residue obtained were designated as crude extracts and stored in a freezer at $-20^{\circ} \mathrm{c}$ until assayed. All the extracts were subjected to qualitative and Quantitative chemical investigation (Kokate CK, 2005). Details of various tests performed for the presence of physiochemical and phytoconstituents in the extracts are as under.

\section{Physicochemical parameters}

The physico-chemical parameters were used to analyze the purity and quality of the extract. The extracts were evaluated for parameters like loss on drying, total ash, acid insoluble ash, water insoluble ash and different extractive values. Ash value is useful in determining authenticity and purity of drugs and also these values are important for quantitative standards. Studied plant materials were evaluated by following physicochemical parameters were given below.

\section{Loss on Drying (LOD)}

Loss on drying is the loss in weight in percent $\mathrm{w} / \mathrm{w}$ resulting from loss of water and volatile matter of any kind that can be driven off under specific conditions. $5 \mathrm{gm}$ of air-dried plant material (extract) was placed in a crucible of silica. The extract was spread in a thin uniform layer. The crucible was then placed in the oven at $105^{\circ} \mathrm{C}$. The extract was dried for 4 hours and cooled in a dessicator to room temperature and weight of the cooled crucible plus powder was noted.

\section{Ash values}

Ash values are indicative to some extent of care taken in collection and preparation of extract of study and for foreign matter content of extract. The object of ashing is to remove all traces of organic material interfering in an analysis of inorganic elements.

Total ash value: This method is designed to measure total amount of material remaining after ignition. $5 \mathrm{gm}$ of extract was taken in tarred platinum crucible. Extract was spread in fine even layer at bottom of the platinum crucible. This platinum crucible with drug material was kept in muffle furnace for ignition at high temperature. Temperature of furnace increased gradually up to $450^{\circ} \mathrm{C}$. The material was kept at this temperature for 6 hours till complete ignition of extract occurred, that is till complete white coloured ash was obtained, intermittent weighing was also done and heating continued till constant weight of crucible. Crucible was then taken out from furnace, cooled and weighed. The total ash was calculated by subtracting the weight of crucible with ash of extract after ignition from weight of crucible with drug powder before ignition. Percentage of total ash was calculated with reference to air-dried drug.

\section{$\%$ Total ash value $=\mathrm{Wt}$ of total ash $/$ Wt of crude drug taken $x 100$}




\section{Preliminary phytochemical investigation}

The plant extract was taken in a test tube and distilled water was added to it such that plant powder soaked in it and shaken well. The solution then filtered with the help of filter paper and filtered extract of the selected plant samples were taken and used for further phytochemical analysis. Phytochemical screening of all the selected medicinal plants was qualitatively tested for the presence of chemical constituents.

The extracts of phytochemical analysis for identification of bioactive chemical constituents were carried out by using standard methods of Sofowora, Trease \& Evans, Kokate, Harbone and Raman (Sofowora A, 1993; Trease GE \& Evans WC, 1994; Kokate CK, 2005; Harbone JB, 1984 and Raman N, 2006).

\section{Detection of Alkaloids}

Mayer's Test: Plant extracts were treated with Mayer's reagent (1.36 mercuric chloride and $5 \mathrm{gms}$ of potassium iodide was dissolved in $100 \mathrm{ml}$ distilled $\mathrm{H}_{2} \mathrm{O}$ ). The formation of yellow cream precipitate indicates the presence of alkaloids.

Wagner's Test: Plant extracts were treated with Wagner's reagent $(1.27 \mathrm{~g}$ iodine, $2 \mathrm{gm}$ potassium iodide inn $100 \mathrm{ml}$ distilled $\mathrm{H}_{2} \mathrm{O}$ ). The formation of brown or reddish precipitate indicates the presence of alkaloids.

\section{Detection of Flavonoids}

Ferric chloride Test: Test solution when treated with few drops of $\mathrm{FeCl}_{3}$ would result in the formation of blackish red colour indicating the presence of flavonoids.

Alkaline Reagent Test: Plant extracts were treated with few drops of $\mathrm{NaOH}$ solution. Formulation of intense yellow colour, which becomes color less on addition of dilute acid indicates the presence of flavonoids.

Lead Acetate Test: Plant extracts were treated with few drops of lead acetate solution. Formation of a yellow precipitate indicates the presence of flavanoids.

\section{Detection of Steroids}

$2 \mathrm{ml}$ of acetic anhydride was added to $0.5 \mathrm{~g}$ ethanolic extract of each sample with $2 \mathrm{ml}$ of $\mathrm{H}_{2} \mathrm{SO}_{4}$. The colour changes from violet to blue or green indicates the presence of steroids.

\section{Detection of Tannins}

To the $1 \mathrm{ml}$ of plant extract, few drops of $1 \%$ $\mathrm{FeCl}_{3}$ solution were added. The appearance of blue, black, green or blue green precipitate indicates the presence of tannins.

\section{Detection of Terpenoids}

Salkowski Test: To the $1 \mathrm{ml}$ of plant extract, $2 \mathrm{ml}$ of chloroform was added. Then $3 \mathrm{ml}$ of conc. $\mathrm{H}_{2} \mathrm{SO}_{4}$ was added carefully to form a layer. A reddish brown coloration of the interface indicates the presence of terpenoids.

\section{Detection of Phenols}

Ferric Chloride Test: To the $1 \mathrm{ml}$ of plant extracts, $3 \mathrm{ml}$ of distilled $\mathrm{H}_{2} \mathrm{O}$ was added. To this few drops of neutral $5 \% \quad \mathrm{FeCl}_{3}$ solution were added. A dark green colour indicates the presence of phenols.

\section{Detection of Saponins}

Foam Test: About $2 \mathrm{ml}$ of distilled $\mathrm{H}_{2} \mathrm{O}$ and $1 \mathrm{ml}$ of plant extract were mixed and shaken vigorously. A stable persistent froth indicates the presence of Saponins.

Froth Test: Plant extracts were diluted with distilled water to $20 \mathrm{ml}$ and this was shaken in a graduated cylinder for 15 minutes. Formation of $1 \mathrm{~cm}$ layer of foam, which is stable for 15 minutes indicates the presence of Saponins.

\section{Detection of Cardiac Glycosides}

Kella - Killani Test: Plant extract was dissolved in glacial acetic acid containing traces of $\mathrm{FeCl}_{3}$. Then the tube was held at an angle of $45^{\circ}, 1 \mathrm{ml}$ of conc. $\mathrm{H}_{2} \mathrm{SO}_{4}$ was added down the side purple ring at the interface indicates cardiac glycosides.

\section{Bacterial Clinical Isolates}

Isolation and Maintainance: Blood samples were taken from patients with clinical positive cases and the samples were then transferred in culture bottles of brain heart infusion broth (Hi Media, Mumbai, India). Bottles were incubated at $36.7^{\circ} \mathrm{C}$ for 7 days. Bottles showing positive growth index were Gram stained and sub cultured on nutrient agar plates, all media were taken from $\mathrm{Hi}$ Media, Mumbai, India. These plates were aerobically incubated for $24-48 \mathrm{~h}$ at $37^{\circ}$ in B.O.D.

Oral swab was taken by gently rubbing a sterile cotton swab over the infected parts. The swabs were incubated in nutrient agar, and other selective media for primary isolation of the pathogens. These plates were then aerobically incubated for $24-48 \mathrm{~h}$ at $37^{\circ} \mathrm{C}$.

When growth was appeared on sub cultured plates of blood and oral swab, all bacterial pathogens were identified by standard microbiological and biochemical procedures. These biochemical tests include carbohydrates fermentation test, urease test, oxidase test, haemolysis of blood, catalase test, motility test and growth of pathogens on specific media etc. [Shimeld LA. 1998; Hawkey P, Law D, 2004; Ryan KJ. 2004; Mukherjee KL. 
2006.].

\section{Determination of Antibacterial activity}

Isolated test bacteria were grown overnight on nutrient agar plates. Bacterial inoculums were prepared from overnight grown cultures $(24 \mathrm{~h})$ in peptone water (Hi Media, Mumbai, India), and the turbidity was adjusted equivalent to $0.5 \mathrm{McF}$ arland units (approximately $10^{8} \mathrm{CFU} / \mathrm{ml}$ ). The microorganisms were inoculated into peptone water and incubated at $35 \pm 2{ }^{\circ} \mathrm{C}$ for $4 \mathrm{~h}$. The positive control was taken ciprofloxacin $(10 \mu \mathrm{g} / \mathrm{ml})$.

The crude extracts of different plants were subjected to antibacterial assay using the Agar Well Diffusion Method of Murray P.R. et al., modified by Olurinola P.F. $20 \mathrm{ml}$ of nutrient agar was dispensed into sterile universal bottles these were then inoculated with $0.2 \mathrm{ml}$ of cultures mixed gently and poured into sterile petridishes. After setting a number 3 -cup borer $(6 \mathrm{~mm})$ diameter was properly sterilized by flaming and used to make four uniform wells in each petridish. A drop of molten nutrient agar was used to seal the base of each cup. To test the antibacterial activity all extracts were dissolved in DMSO to make a final concentration of $100 \mathrm{mg} / \mathrm{ml}$ and the wells are filled with $20 \mu$ l of the extract and allow diffusing for 45 minutes. These plates were incubated for a period of $24 \mathrm{~h}$ at $37^{\circ} \mathrm{C}$ in incubator. The zones of inhibition were measured with antibiotic zone scale in $\mathrm{mm}$ and the experiment was carried out in duplicates. The average value of inhibition and standard deviation were calculated. The zone of inhibition was compared with that of standard ciproflaxacin $10 \mu \mathrm{g} / 1000 \mu \mathrm{l}$.

\section{Determination of MIC}

Minimum Inhibitory Concentration (MIC) were determined by broth dilution assay method. For the determination of MIC, the reconstituted extract in DMSO was serially diluted in Muller Hinton broth medium to get the concentrations of $\mathrm{mg} / 1000 \mu \mathrm{l}$.

The MIC values of extracts were determined based on a microbroth dilution method in 96 multi-well microtitre plates with slight modifications. The crude plant extracts were first diluted to the highest concentration, 500 to $25 \mathrm{mg} / \mathrm{ml}$ ), to be tested, and $50 \mu \mathrm{l}$ of normal saline was distributed from the second to the ninth well. A volume of 50 $\mu \mathrm{l}$ from each extracts was pipetted into the first test well of each microtitre line which acts as sterility control, and then $50 \mu \mathrm{l}$ of scalar dilution of plant extract was transferred from the second to the ninth well. To each well was added $10 \mu$ l of resazurin indicator solution (prepared by dissolving a $270 \mathrm{mg}$ tablet in $40 \mathrm{ml}$ of sterile distilled water). Using a pipette $30 \mu$ l of Muller Hinton broth was added to each well to ensure that the final volume was of single strength of the normal saline. Finally, $10 \mu \mathrm{l}$ of the bacterial suspensions were added to each well. In each plate, a column with a broad-spectrum antibiotic was used as the positive control (Ciprofloxacin in serial dilution 500 to $25 \mathrm{mg} / \mathrm{ml}$ ).

The plates were wrapped loosely with cling film to ensure that bacterium did not become dehydrated, and were prepared in triplicate. Subsequently, they were placed in an incubator at $37^{\circ} \mathrm{C}$ for $24 \mathrm{~h}$. Any color change from purple to pink or to colorless was recorded as positive. The lowest concentration at which the color change occurred was taken as the MIC value. The average of three values was calculated to determine the MIC of the test material.

\section{Results and Discussion \\ Physiochemical properties}

Analysis of Physicochemical constants of the medicinal plants has studied to evaluate the quality and purity of the extracted compounds from plant materials. Various physicochemical parameters like Ash and Extractive values were calculated as per WHO guidelines. The information collected from these tests was useful for standardization and obtaining the quality standards. The results of the physicochemical constants of medicinal plants lie within the limit which is mentioned in below table signifies that the quality and purity of raw material was good enough. The total ash is particularly important in the evaluation of purity of drugs, i.e. the presence or absence of foreign matter such as metallic salts or silica.

\section{Loss on drying}

The loss of weight was calculated as the content in $\mathrm{mg}$ per $\mathrm{g}$ of air-dried material. The percent loss on drying was then calculated for each plant powder. The results obtained were reported in fig. 1 . Percentage of loss on drying was highest in Rosmarinus officinalis (18.22 \pm 1.05$)$ and least in Punica granatum (5.28 1.05$)$.

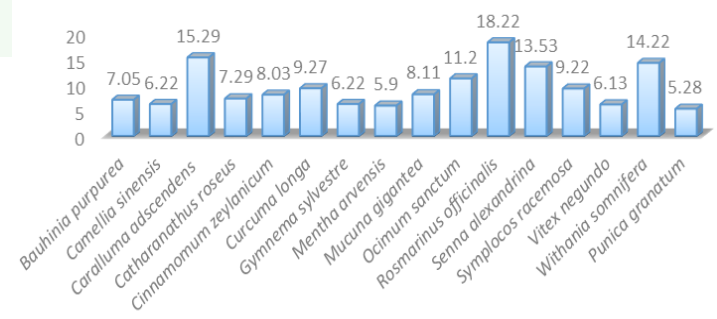

Figure 1: Physicochemical analysis of $\%$ of loss on drying

\section{Ash values}

The total ash is particularly important in the evaluation of purity of extract, the ash values of medicinal plants of studied were determined and 
the results were shown in fig. 2. The amount and composition of ash remaining after combustion of plant material varies considerably according to the part of the plant, age, treatment etc. The constituents of the ash also vary with time and from organ to organ. Ash usually represents the inorganic part of the plant. It contains inorganic material of the plant because ashing destroys all the organic material present in the sample. Ash values mainly reflects the presence of high inorganic content. However, the ash content is possibly due to the $\mathrm{Na}+$ and $\mathrm{Ca} 2+$ salts which are not harmful. Heavy metals are being spoken out vary widely in the global scenario, due to the recent episodes of a few Indian Ayurvedic formulations which have been found to have heavy metals more than that of the permissible level as advised by W.H.O. and F.A.O. The percentage of macronutrients like sodium, potassium and magnesium were within the stipulated limits. Toxic heavy metals like arsenic, lead, palladium and mercury were within the limit and ensure the safety of the study.

At present investigation we found that the percentage of total ash content was highest in Senna alexandrina with value $9.23 \pm 1.02$ and least value is $2.42 \pm 0.12$ for Catharanathus roseus.

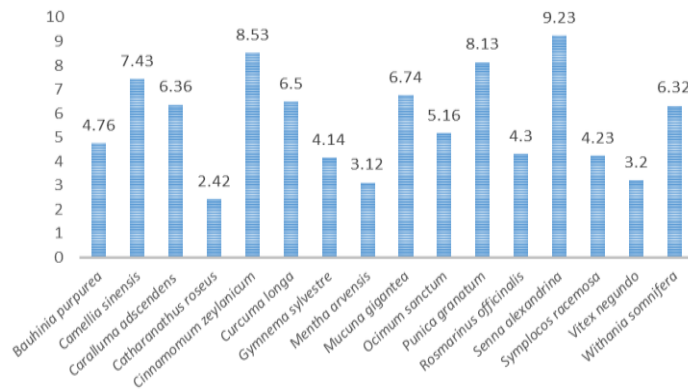

Figure 2: Physicochemical analysis of plants ash

\section{Preliminary phytochemical screening}

Medicinal properties of plants are perhaps due to the presence of various secondary metabolites such as alkaloids, flavonoids, glycosides, phenols, saponins, sterols etc. The results of preliminary phytochemical analysis are shown in Table 2 . The preliminary phytochemical screening tests may be useful in the detection of the bioactive principles and subsequently may lead to the drug discovery and development. Further, these tests facilitate their quantitative estimation and qualitative separation of pharmacologically active chemical compounds.

Table 2: Qualitative phytochemical analysis of sixteen medicinal plants of methanol extract

\begin{tabular}{|c|c|c|c|c|c|c|c|c|c|c|}
\hline Pant Name & Terpenoid & Flavinoid & Alkaloid & glycoside & phenol & $\begin{array}{l}\text { Cardiac } \\
\text { glycoside }\end{array}$ & Tannins & Coumarins & Quinone & Saponin \\
\hline Baubinia purpurea & + & + & + & + & + & + & + & + & + & + \\
\hline Camellia sinensis & + & + & + & + & + & + & + & & & \\
\hline Caralluma adscendens & + & - & - & - & + & - & + & - & - & + \\
\hline Catharanathus roseus & - & - & + & + & + & - & + & + & + & + \\
\hline $\begin{array}{l}\text { Cinnamomum } \\
\text { zeylanicum }\end{array}$ & + & - & + & + & + & - & + & + & + & + \\
\hline Curcuma longa & + & - & + & + & - & + & + & - & + & + \\
\hline Gymnema sylvestre & + & + & + & + & + & + & + & + & + & + \\
\hline Mentha arvensis & & + & & & + & + & + & & & \\
\hline Mucuna gigantean & + & + & + & & + & & + & & & + \\
\hline Ocimum sanctum & + & + & + & + & + & + & - & + & + & + \\
\hline Punica granatum & + & + & - & + & + & + & + & + & + & - \\
\hline Rosmarinus officinalis & + & + & - & - & + & - & - & - & - & - \\
\hline Senna alexandrina & + & + & + & + & + & + & + & + & + & + \\
\hline Symplocos racemosa & + & + & + & + & + & + & + & + & + & + \\
\hline Vitex negundo & + & & + & + & & + & & & + & + \\
\hline Withania somnifera & + & + & + & + & + & + & + & + & + & + \\
\hline
\end{tabular}

$(+)$, presence. (-), Absence.

\section{Antibacterial activity}

In the present study the predominant bacterial pathogens isolated were Staphylococcus aureus, Escherichia coli, Klebsiella pneumonea and Proteus vulgaris. The methanol extracts of sixteen medicinal plants were screened against four bacterial strains. The antimicrobial activity of different extracts on different bacterial clinical isolates has been shown in Table 3. K. pneumonea exhibited good susceptibility to all the extracts studied. Catharanathus roseus, Camellia sinensis, Rosmarinus officinalis, Baubinia purpurea, Ocimum sanctum, Punica granatum, Senna alexandrina and Withania somnifera revealed significant antibacterial activity. Our study revealed P.vulgaris as most resistance bacterial species due to very limited activity observed in all plant extracts. K. pneumonea which is considered as susceptible to all studied extracts. Out of selected medicinal plants C.roseus exhibited good antibacterial activity against all clinical pathogens studied. 
Table 3: Antibacterial activity of methanol extracts on Clinical isolates

\begin{tabular}{|c|c|c|c|c|c|}
\hline \multirow{2}{*}{ Plant Name } & E. coli & $P$. vulgaris & $K \cdot$ pneumonea & S. aureus & \multirow[t]{2}{*}{ MIC } \\
\hline & \multicolumn{4}{|c|}{ zone of inhibition in $\mathrm{mm}$} & \\
\hline Baubinia purpurea & 15 & 14 & 15 & 9 & $75 \pm 1.25 \mathrm{mg} / \mathrm{ml}$ \\
\hline Camellia sinensis & 17 & 15 & 15 & 12 & $50 \pm 0.65 \mathrm{mg} / \mathrm{ml}$ \\
\hline Caralluma adscendens & 7 & 8 & 15 & 12 & $75 \pm 1.05 \mathrm{mg} / \mathrm{ml}$ \\
\hline Catharanathus roseus & 18 & 22 & 19 & 24 & $25 \pm 0.55 \mathrm{mg} / \mathrm{ml}$ \\
\hline Cinnamomum zeylanicum & 7 & 8 & 10 & 7 & $100 \pm 0.50 \mathrm{mg} / \mathrm{ml}$ \\
\hline Curcuma longa & 11 & 12 & 8 & 8 & $100 \pm 1.25 \mathrm{mg} / \mathrm{ml}$ \\
\hline Gymnema sylvestre & 14 & 15 & 16 & 12 & $75 \pm 1.10 \mathrm{mg} / \mathrm{ml}$ \\
\hline Mentha arvensis & 7 & 8 & 9 & 9 & $100 \pm 0.25 \mathrm{mg} / \mathrm{ml}$ \\
\hline Mucuna gigantea & 16 & 9 & 12 & 15 & $100 \pm 0.50 \mathrm{mg} / \mathrm{ml}$ \\
\hline Ocimum sanctum & 16 & 10 & 19 & 12 & $75 \pm 0.15 \mathrm{mg} / \mathrm{ml}$ \\
\hline Punica granatum & 15 & 16 & 15 & 15 & $50 \pm 2.25 \mathrm{mg} / \mathrm{ml}$ \\
\hline Rosmarinus officinalis & 16 & 18 & 17 & 18 & $25 \pm 3.50 \mathrm{mg} / \mathrm{ml}$ \\
\hline Senna alexandrina & 15 & 12 & 16 & 14 & $75 \pm 2.25 \mathrm{mg} / \mathrm{ml}$ \\
\hline Symplocos racemosa & 11 & 7 & 11 & 10 & $100 \pm 2.00 \mathrm{mg} / \mathrm{ml}$ \\
\hline Vitex negundo & 12 & 9 & 10 & 9 & $100 \pm 1.50 \mathrm{mg} / \mathrm{ml}$ \\
\hline Withania somnifera & 8 & 15 & 15 & 15 & $75 \pm 0.15 \mathrm{mg} / \mathrm{ml}$ \\
\hline Antibiotic & 22 & 29 & 32 & 28 & $10 \mu \mathrm{g} / \mathrm{ml}$ \\
\hline
\end{tabular}

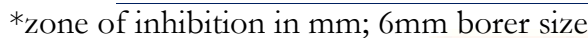

The MIC studied extracts against clinical isolates has been listed in Table 3. The MIC ranges from 25 to $100 \mathrm{mg} / \mathrm{ml}$. The potency of the extract based on the zones of inhibitions, was compared with standard commercial available antibiotics such as ciprofloxacin $(10 \mu \mathrm{g} / \mathrm{ml})$ observed that the antimicrobial activity of crude extracts was less than those of the standard drugs.

\section{Discussion}

From the research it was observed that all extracts exhibited antibacterial activity against clinical isolate bacteria and inhibition zone was observed ranged from 7 to $25 \mathrm{~mm}$. As it is well known that $P$. vulgaris is notorious for its resistance to antibiotics and is, therefore particularly dangerous and dreaded pathogen. The bacterium is naturally resistance to many antibiotics due to the permeability barriers afforded by its outer membrane composed of lipopolysaccharide (LPS). One method to reduce the resistance to antibiotics is by using antibiotics resistance inhibitors from plant origin (Iinuma M, et al., 1994; Kim H, et al., 1995). We have observed very significant antibacterial activity of $C$ roseus and $O$. sanctum extracts, against $K$. pneumonea. These results revealed that the antibacterial activity of $C$. roseus extracts hold the most promise for further work.

In our study various phytochemicals compounds alkaloids, cardiac glycosides, flavonoids, saponins, terpenes, tannins, phenols, coumarins and quinones were identified from sixteen medicinal plants. The antimicrobial susceptibility of studied medicinal plants could be attributed to the presence of these antimicrobial compounds, which is also proved by other studies [Ahmed AA, et al., 1993; Batista O, et al., 1994; Tsuchiya H, et al., 1996; Rabe T, Van Stadin VJ, 1997; Barre JT, et al., 1997; Amaral JA, et al., 1998; Cowan CC. 1999; Santhi R, et al., 2006].
The results of our research highlights, the fact that the methanol extracts exhibited greater antimicrobial activity because the antimicrobial principles were either polar or non-polar and they were extracted only through the organic solvent medium [Mohanasundari C, et al., 2007; Britto JS, 2001]. So the present observation suggests that the methanol solvent extraction was suitable to verify the antimicrobial properties of medicinal plants which are also supported by many other investigators [Krishna KT, et al., 1997; Singh I, Singh VP., 2000; Natarajan E, et al., 2003; Natarajan D, et al., 2005].

\section{Conclusion}

The present investigation reported that Indianherbal medicine may possess antimicrobial activity against the clinical isolates. These research findings can form the basis for further studies to isolate active compounds, elucidate the structures, and also evaluate them against wider range of resistance bacterial and fungal strains with the goal to find new therapeutic principles. In conclusion, the results of this study have provided scientific justification for the use of Catharanathus roseus, Camellia sinensis, Rosmarinus officinalis, Baubinia purpurea, Ocimum sanctum, Punica granatum, Senna alexandrina and Withania somnifera extracts as antimicrobial agents. The extracts of these medicinal plants possess a broad spectrum of activity against a panel of bacteria responsible for the most common bacterial diseases. These promissory extracts open the possibility of finding new clinically effective antibacterial compounds, thereby decreasing the burden of drug resistance and cost of management of diseases. The result shows that the use of $C$. roseus plant in treating microbial infections apart from its anticancer properties could be exploited for new potential antibiotics. However, the effect of the above plants on more pathogenic organisms, toxicological investigations and further purifications, needs to be carried out. 


\section{References}

1. Ahmed AA, Mahmoud AA, Williams HJ, Scott AI, Reibenspies JH, Mabry TJ. New sesquiterpene a-methylene lactones from the Egyptian plant Jasonia candicans. Journal Natural Products. 56: 1993, 1276-1280.

2. Amaral JA, Ekins A, Richards SR, Knowles R. Effect of selected monoterpenes on methane oxidation, denitrification, and aerobic metabolism by bacteria in pure culture. Applied Environmental Microbiology. 64: 1998, 520-525.

3. Barre JT, Bowden BF, Coll JC, Jesus J, Fuente VE, Janairo GC, Ragasa CY. A bioactive triterpene from Lantana camara. Phytochemistry. 45: 1997, 321-324.

4. Batista O, Duarte A, Nascimento J, Simones MF. Structure and antimicrobial activity of diterpenes from the roots of Plectranthus hereroensis. Journal Natural Products. 57: 1994, 858-861.

5. Britto JS. Comparative antibacterial activity study of Solanum incanum L. Journal Swamy Botany Club. 18: 2001, 81-82.

6. Cowan CC. Plant Products as Antimicrobial Agents. Clinical Microbiology Review. 12(4): 1999, 564-582.

7. Cragg GM, Newman DJ. Natural product drug discovery in the next millennium. Pharm Biol. 39(Supplement): 2001:8-17.

8. D'Costa VM, et al., Antibiotic resistance is ancient. Nature. 477 (7365):2011: 457-61.

9. Farombi EO. African indigenous plants with chemotherapeutic potentials and biotechnological approach to the production of bioactive prophylactic agents. Afr J Biotechnol. 2(12): 2003:662-671.

10. Harborne JB. Phytochemical Methods; A guide to Modern Technique of Plant Analysis, 2nd ed. Chapman, 1984, p.100-101.

11. Hawkey P, Law D. Medical Bacteriology. 2. Oxford University Press, New York; 2004.

12. Iinuma M, Tsuchiya H, Sato M, Yokoyama J, Ohyama M, Ohkawa Y, Tanaka T, Fujiwara S, Fujii T. Flavanones with potent antibacterial activity against methicillin-resistant Staphylococcus aureus. Journal of Pharmaceutical Pharmacology. 46: 1994, 892895. [PubMed]
13. Khan R, Islam B, Akram M, Shakil S, Ahmad A, Ali SM, Siddiqui M, Khan AU: Antimicrobial activity of five herbal extracts against Multi Drug Resistant (MDR) strains of bacteria and fungus of clinical origin. Molecules, 14:2009:586-597.

14. Kim H, Park SW, Park JM, Moon KH, Lee CK. Screening and isolation of antibiotic resistant inhibitors from herb materials IResistant Inhibition of 21 Korean Plants. Natural Product Science. 1: 1995, 50-54.

15. Kokate CK. Practical pharmacognosy. Published by Jain MK for Vallabh Prakashan, Pitampura, New Delhi; 2005. p. 107.

16. Krishna K'T, Ranjini CE, Sasidharan VK. Antibacterial and antifungal activity of secondary metabolites from some medicinal and other common plant species. Journal Life Sciences. 2: 1997, 14-19.

17. Mohanasundari C, Natarajan D, Srinivasan K, Umamaheswari SA, Ramachandran A. Antibacterial properties of Passiflora foetida L. -a common exotic medicinal plant. African Journal Biotechnology. 6(23): 2007, 2650 2653.

18. Mukherjee KL. In: A procedure manual for routine diagnostic test. Tata Mac, editor. II. Grew Hill publishing compd. Limited; 2006.

19. Natarajan D, Britto JS, Srinivasan K, Nagamurugan N, Mohanasundari C, Perumal G. Anti-bacterial activity of Euphorbia fusiformis- a rare medicinal herb. Journal of Ethnopharmacology. 102: 2005, 123-126.

20. Natarajan E, Senthilkumar S, Xavier FT, Kalaiselvi V. Antibacterial activities of leaf extracts of Alangium salviifolium. Journal Tropical Medicinal Plants. 4: 2003, 9-13.

21. Rabe T, Van Stadin VJ. Antibacterial of South African plants used for medicinal purposes. Journal of Ethnopharmacology. 56: 1997, 8187.

22. Raman N. Phytochemical Techniques. New Indian Publishing Agencies, New Delhi, 2006, p. 19.20 .

23. Robbers $J$, Speedie M, Tyler V: Pharmacognosy and pharmacobiotechnology. Williams and Wilkins, Baltimore; 1996.

24. Ryan KJ. In: Medical Microbiology. Fourth. Sherris JC, Ryan KJ, Ray GC, editor. McGraw Hill, USA; 2004. Normal Microbial flora. 
25. Santhi R, Alagesaboopathi C, Pandian MR. Antibacterial activity of Andrographis lineata Nees and Andrographis echioides Nees of Shevaroy hills of Salem District, Tamil Naidu. Advance concepts in Plant Sciences. 19(II): 2006, 371-375.

26. Shimeld LA. Essential of Diagnostic Microbiology. International Thomas Publishing Company, USA; 1998.

27. Singh I, Singh VP. Antifungal properties of aqueous and organic solution extracts of seed plants against Aspergillus flavus and A. niger. Phytomorphol. 50: 2000, 151-157.

28. Sofowora A. Medicinal plants and Traditional Medicine in Africa. Spectrum Books Ltd (Pub.). Ibadan. 17. 1993, 1-153.
29. Trease GE and WC Evans. Pharmacognosy. Bailliere Tindall, London, 18, 1989, 45-50.

30. Tsuchiya H, Sato M, Miyazaki T, Fujiwara S, Tanigaki S, Ohyama M, Tanaka T, Iinuma M. Comparative study on the antibacterial activity of phytochemical flavanones against methicillin-resistant Staphylococcus aureus. Journal of Ethnopharmacology. 50: 1996, 27 34.

\section{Cite this article as:}

Phani Kumari Uddandapu, K. Chandrasekhara Naidu, Y. Venkateswar Rao. Physiochemical, phytochemical and antibacterial studies of few medicinal plants of Visakhapatnam region against bacterial clinical isolates. Annals of Plant Sciences 5.3 (2016): 1296-1303.
Source of support: Nil

Conflict of interest: None Declared 